Mycologia, 103(4), 2011, pp. 000-000. DOI: 10.3852/10-355

(C) 2011 by The Mycological Society of America, Lawrence, KS 66044-8897

\title{
New species and distribution records of Clavulina (Cantharellales, Basidiomycota) from the Guiana Shield
}

Terry W. Henkel ${ }^{1}$

Department of Biological Sciences, Humboldt State University, Arcata, California 95521

M. Catherine Aime

Department of Plant Pathology E Crop Physiology, 302 Life Sciences Building, Louisiana State University Agricultural Center, Baton Rouge, Louisiana 70803

Jessie K. Uehling

Department of Biological Sciences, Humboldt State University, Arcata, California 95521

Matthew E. Smith

Department of Biology, Duke University, Durham, North Carolina 27708

Abstract: Two new species of Clavulina Schroet. (Clavulinaceae, Cantharellales, Basidiomycota) and new distribution records for Clavulina amazonensis Corner and Clavulina sprucei (Berk.) Corner are described from the Pakaraima Mountains of Guyana, in the central Guiana Shield region. These fungi occur in rainforests dominated by ectomycorrhizal (ECM) trees of the leguminous genus Dicymbe (Fabaceae subfam. Caesalpinioideae). Macromorphological, micromorphological and habitat data are provided for each species. Nuclear ribosomal DNA sequences of the internal transcribed spacer region and 28S subunit were obtained from the type and other collections of each new species and from representative collections of $C$. amazonensis and $C$. sprucei. The two new species, Clavulina kunmudlutsa sp. nov. and Clavulina tepurumenga sp. nov., constitute important edible fungi for the Patamona Amerindians. Our specimens of C. sprucei represent the first reports of the species since 1853 as well as a range extension of nearly $1500 \mathrm{~km}$, while sequence data from basidiomata as well as ECM roots suggest that this taxon consists of a cryptic species complex.

Key words: clavarioid fungi, ectomycorrhiza, Guyana, Neotropics, systematics, taxonomy

\section{INTRODUCTION}

In ectotrophic forests of the central Guiana Shield taxa of the clavarioid genus Clavulina Schroet. (Clavulinaceae, Cantharellales, Basidiomycota) form a

Submitted 5 Nov 2010; accepted for publication 8 Dec 2010.

${ }^{1}$ Corresponding author. E-mail: twh5@humboldt.edu conspicuous component of the macromycota (Henkel et al. 2002, 2005; Thacker and Henkel 2004). In the Pakaraima Mountains of Guyana approximately 20 morphospecies of Clavulina, nearly half of which remain undescribed, occur in forests dominated by ectomycorrhizal (ECM) trees of genus Dicymbe (Fabaceae subfam. Caesalpinioideae; Aime and Henkel 2008). This a significant number considering that 71 Clavulina species have been described worldwide, most with tropical distributions (Corner 1950, 1970; Petersen 1967, 1983, 1985, 1988a, b; Thind 1961; Thind and Sharda 1984; Roberts 1999; Thacker and Henkel 2004; Henkel et al. 2005; Douanla-Meli 2007; Duhem and Buyck 2007). The ECM status of several Clavulina species in Guyana has been confirmed by direct sequencing of ectomycorrhizal roots of Dicymbe corymbosa Spruce ex Benth., Dicymbe altsonii Sandw. and Aldina insignis (Benth.) Endl. (Fabaceae subfam. Papilionoideae, Smith and Henkel unpubl data) and was corroborated by the recovery of Clavulina sequences from ectomycorrhizas of other Neotropical trees (Moyersoen 2006, Tedersoo et al. 2010). Several of the Guyanese Clavulina taxa are highly prized as food by the Patamona Amerindians (Henkel et al. 2004). Here we describe Clavulina kunmudlutsa sp. nov. and Clavulina tepurumenga sp. nov. and present new distribution records for Clavulina amazonensis Corner and Clavulina sprucei (Berk.) Corner. Macromorphological, micromorphological, habitat and DNA sequence data are provided for each species. Clavulina amazonensis has been recorded from central Brazil and southern Venezuela (Corner 1970, Petersen 1988b), but our collections of C. sprucei constitute a range extension of nearly $1500 \mathrm{~km}$ and are the first records for the species since Richard Spruce collected the Brazilian holotype in 1853.

\section{MATERIALS AND METHODS}

Collections. - Collections were made during the May-Jul 2000-2004, 2008 and 2010 rainy seasons and the Dec 2009 rainy season from the Upper Potaro River Basin, within a $15 \mathrm{~km}$ radius of a permanent base camp at $5^{\circ} 18^{\prime} 04.8^{\prime \prime} \mathrm{N}$, $59^{\circ} 54^{\prime} 40.4^{\prime \prime} \mathrm{W}, 710 \mathrm{~m}$ (Henkel 2003). Additional collections of C. amazonensis were made 1998-1999 from the Upper Ireng River Basin approximately $30 \mathrm{~km}$ south of the Potaro site (Henkel et al. 2002). Basidiomata were collected from forests dominated by $D$. corymbosa and other stands containing D. corymbosa, D. altsonii Sandw. and A. insignis. Ectomycorrhizal roots were sampled beneath trees of these 
three host plant species in Jan 2010 (Smith and Henkel 2010). Macroscopic features of basidiomata were described fresh in the field. Colors were described subjectively and coded according to Kornerup and Wanscher (1978), with color plates noted in parentheses. Fungi were field dried with silica gel. Additional specimens housed at TENN of previously undetermined clavarioid fungi from Guyana and Venezuela were examined. Type specimens of three Brazilian Clavulina species were examined at Kew.

Micromorphological features of fresh specimens were examined with an EPOI field microscope with light optics; dried specimens were examined with an Olympus BX51 microscope with light and phase contrast optics. For basidiospores, basidia and other structures at least 20 individuals were measured. Rehydrated fungal tissue was mounted in $\mathrm{H}_{2} 0,3 \% \mathrm{KOH}$ and Melzer's solution. Line drawings were made from digital photographs. Specimens are deposited in these herbaria (Holmgren, Holmgren and Barnett 1990): BRG, University of Guyana; HSU, Humboldt State University; LSUM, Louisiana State University (Mycology); NY, New York Botanical Garden; DUKE, Duke University Herbarium; FH, Farlow Herbarium; TENN, University of Tennessee (Fungus Herbarium); K(M), Royal Botanic Gardens, Kew, Mycology Section.

DNA extraction, polymerase chain reactions (PCR), DNA sequencing and phylogenetic analyses.-DNA extractions were performed on basidiomata and ECM roots that were either rapidly dried in the field with silica gel or stored in $2 \times$ CTAB extraction buffer. Tissues were homogenized with sterile forceps or a micropestle, and DNA was extracted with either a standard CTAB protocol (Gardes and Bruns 1993) or the Extract-N-Amp DNA kit (Sigma-Aldrich Ltd., St Louis, Missouri). The ITS1-5.8s-ITS2 (ITS) and partial large subunit (28S) of the ribosomal DNA were amplified with the forward primers ITS1F and LROR and the reverse primers ITS4, LR3, LR5 in various combinations with protocols of Vilgalys and Hester (1990), Gardes and Bruns (1993) and Tedersoo et al. (2008). PCR products were viewed on $1.5 \%$ agarose gels stained with SYBR Green I (Molecular Probes, Eugene, Oregon). Amplicons were cleaned with EXO (Exonuclease I) and SAP (shrimp alkaline phosphatase) enzymes (Glenn and Schable 2005) and sequenced with the Big Dye sequencing kit 3.1 (Applied Biosystems, Foster City, California) and the same primers. Sequencing reactions were cleaned and processed on an ABI 3730xl genetic analyzer (Applied Biosystems, Foster City, California) at the Duke University Genome Sequencing \& Analysis Core Facility. Generic affinities of taxa were determined with BLAST queries and phylogenetic analysis. DNA sequences of ITS rDNA from basidiomata and ectomycorrhizas of the C. sprucei species complex were compiled in Mesquite 1.1 (Maddison and Maddison 2006) and aligned with the aid of MUSCLE (Edgar 2004). Parsimony analysis was performed with the default settings and parsimony bootstrapping with 500 replicates in PAUP 4.0a112 (Swofford 2002). Maximum likelihood bootstrapping was performed with 500 replicates using the default settings in Garli 0.951 (Zwickl 2006). All sequences were deposited on GenBank.

\section{TAXONOMY}

Clavulina kunmudlutsa T.W. Henkel et Aime, sp. nov.

FIGS. 1, 2

\section{MycoBank MB518848}

Clavulina kunmudlutsa basidiomi amplitudine, stature, basidiospore amplitudine et fibulium hypharum tramae cellularum amplitudine neotropicae Clavulinae panurensis (Berk.) Corner similis, sed armeniacis vel aurantiacis basidomatis cum ramis rotundis non-complanatis, longioribus basidiis, $47-69(77) \mu \mathrm{m}$ vs. $36-50 \mu \mathrm{m}$, et basidiosporis semper uniguttulatis differt.

Basidiomata coralloid, terrestrial, arising from organic/mineral soil interface, in caespitose clusters, more rarely solitary, free or slightly fused basally, with acuminate basal primordia initially monopodial but branching early with expansion; caespitose clusters 75-120(160) $\mathrm{mm}$ tall, 25-88 $\mathrm{mm}$ across branches, 8$25 \mathrm{~mm}$ across basal stipe cluster; individual basidiomata branching 3-4 times in multiple planes, branching pattern dichotomous-ascending, internodes progressively shorter upward, resulting in subcoronate apices, apices initially acuminate, progressively more blunt-rounded with hymenial thickening, branches initially rounded throughout, texture pliant-cartilaginous; sterile stipe $20-35(-70) \times 8-$ $15 \mathrm{~mm}$, dull orange (5A4-5A5) to brownish orange (5B7-5C7), glabrous, extreme basal mycelium pale buff-orange, tomentulose; fertile branches 3580 (105) $\mathrm{mm}$ long, 1-4 mm wide, slightly flattened with age; hymenium ripening over distal two-thirds of basidioma, amphigenous, interface with stipe sharply demarcated and angular, initially nearly concolorous with base, maturing to light pinkish orange (5A3-6A3$6 \mathrm{~A} 4)$ and eventually to pale grayish orange (5B4-6B4), thickening substantially from $0.2-0.8 \mathrm{~mm}$, smooth, eventually subrugulose and obscuring apical tips, distorted with blunt tips with advanced age, finely hispid under handlens, moist; trama with hollow core in stipe, solid apically, orangish brown, lighter orange in branches. Spore deposit not obtained. Odor fragrant, fruity, chanterelle-like; flavor nutty, somewhat tangy.

Basidiospores 7-9 × 6-7 $\mu \mathrm{m}$ (mean $\mathrm{Q}=1.27$ ), subellipsoid, smooth, hyaline in $\mathrm{H}_{2} \mathrm{O}$, pale yellow in $\mathrm{KOH}$, inamyloid, with one translucent guttule; wall $1 \mu \mathrm{m}$ thick; hilar appendage 1-1.25 $\mu \mathrm{m}$ long. Basidia (40)47-69(77) $\mu \mathrm{m}$ long, 5-7 $\mu \mathrm{m}$ wide at apex, 4.9$6.2 \mu \mathrm{m}$ at center, $3-5 \mu \mathrm{m}$ at base, cylindrical to subclavate, tapering evenly toward base, with grayish granular contents; postpartal septa regularly observed, occurring 12-27 $\mu \mathrm{m}$ below apex; sterigmata 5-9 $\mu \mathrm{m}$ long, cornute, two per basidium. Basidioles numerous. Cystidia none. Hymenium in transverse section 111-613 $\mu \mathrm{m}$ thick. Tramal hyphae smooth, thin-walled, hyaline, lacking internal contents; cells 

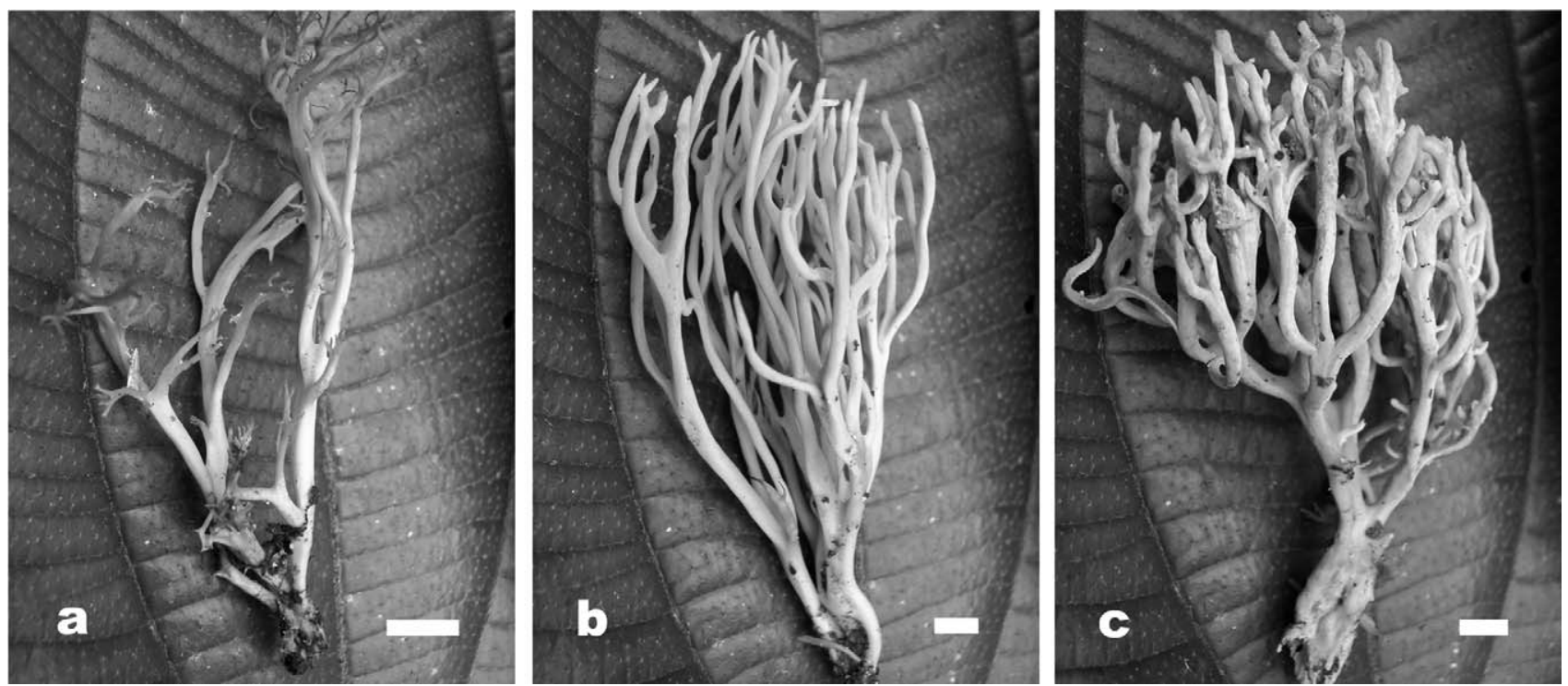

FIG. 1. Basidiomata of Clavulina kunmudlutsa (HOLOTYPE; Henkel 8932). a, b, c. Progressive hymenial development. Bar $=10 \mathrm{~mm}$.

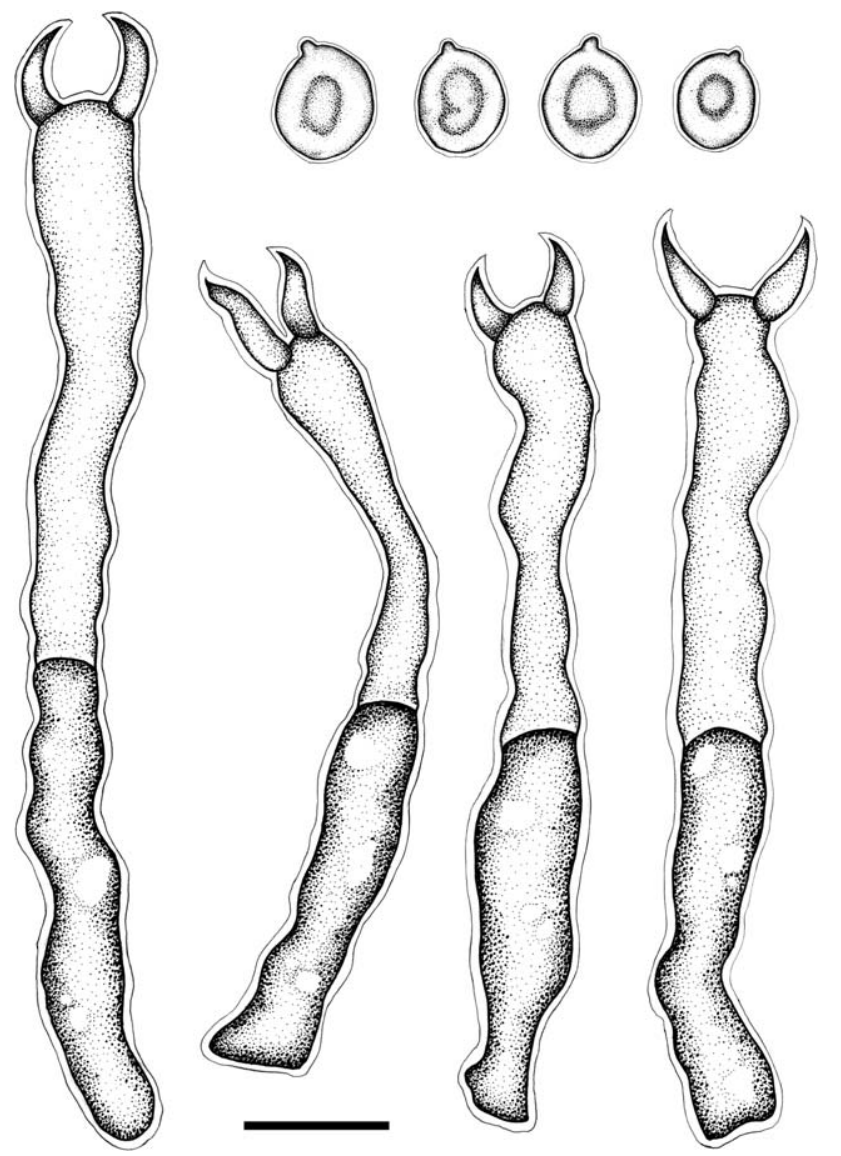

FIG. 2. Basidia and basidiospores of Clavulina kunmudlutsa (HOLOTYPE; Henkel 8932). Bar $=10 \mu \mathrm{m}$.
37-93(103) $\mu \mathrm{m}$ long; uninflated elements 4-11 $\mu \mathrm{m}$ wide; inflated elements up to $20 \mu \mathrm{m}$ wide. Clamp connections abundant.

Holotype. Henkel 8932 (BRG; ISOTYPE HSU; NY; DUKE)

Habit, habitat and distribution. Scattered to occasionally gregarious on sandy soils, more rarely on lateritic clay soils, in rainforest dominated by $D$. corymbosa; common throughout May-Jul rainy season; basidiomata persistent 1-3 wk. Known from the Upper Potaro Basin east of Mount Ayanganna and east of Kopinang Mountain in the Pakaraima Mountains of Guyana.

Etymology. Kunmudlutsa is the vernacular name applied to this fungus by the Patamona Amerindians, who collect it as an edible species.

Specimens examined. GUYANA. REGION 8 POTAROSIPARUNI: Pakaraima Mountains, Upper Potaro River Basin, within $10 \mathrm{~km}$ radius of $5^{\circ} 18^{\prime} 04.8^{\prime \prime} \mathrm{N}, 59^{\circ} 54^{\prime} 40.4^{\prime \prime} \mathrm{W}$, $710-750 \mathrm{~m} ; 0.4 \mathrm{~km}$ southwest of base camp near confluence of Blackwater Creek and Potaro River, 9 Jun 2000, Henkel 7463 (BRG; HSU); $3.5 \mathrm{~km}$ west of base camp near Dicymbe plot 3, 23 May 2001, Henkel 8207 (BRG; HSU); vicinity of base camp, 13 Jun 2002, Henkel 8460 (BRG; HSU); 1.5 km east of base camp near Leon's camp on white sand soils, 11 Jul 2008, Henkel 8932 (HOLOTYPE BRG; ISOTYPE HSU, NY; DUKE; ITS and partial 28S GenBank accession number HQ680359); $2.5 \mathrm{~km}$ west of base camp near Dicymbe plot 3 on gray sands, 21 May 2010, Henkel 9206 (BRG; HSU; ITS and partial 28S GenBank accession number HQ680358); vicinity of old Ayanganna airstrip on white sand soils, 19 May 2000, Aime 967 (BRG; LSUM); west side of old Ayanganna airstrip, 24 May 2000, Aime 1015 
(BRG; LSUM); $1.5 \mathrm{~km}$ west of base camp near Dicymbe plot 3, 27 Jun 2006, Aime 3117 (BRG; LSUM; 28S GenBank accession number HQ680362); $2.5 \mathrm{~km}$ southeast of base camp near Dicymbe plot 1, 15 May 2010, Aime 3926 (BRG; LSUM); Kopinang Mountain, SE slope along KopinangOrinduik Trail, $1.5 \mathrm{~h}$ walk $\mathrm{S}$ of Kopinang Village on steep slope, near $4^{\circ} 57^{\prime} 0.0^{\prime \prime} \mathrm{N}, 59^{\circ} 53^{\prime} 0.0^{\prime \prime} \mathrm{W}, 750-790 \mathrm{~m}$, on ground under caesalpinioid legumes, 22 Jul 1989, Samuels 6660 (TENN 51393!); $~ 4.5 \mathrm{~h}$ walk NE of Kopinang Village, near $5^{\circ} 03^{\prime} 0.0^{\prime \prime} \mathrm{N}, 59^{\circ} 48^{\prime} 0.0^{\prime \prime} \mathrm{W}, 640 \mathrm{~m}$, on ground along creek in Dicymbe-dominated forest, 19 Jul 1989, Samuels 6624 (TENN 51402!).

Commentary. Clavulina kunmudlutsa is recognized in the field by its relatively large, branching, pinkish orange basidiomata that are found scattered to gregarious on the forest floor under D. corymbosa. In addition in the type locality of Guyana's Upper Potaro Basin C. kunmudlutsa fruits preferentially in Dicymbe forests on white sand soils. The cartilaginous texture and the thickening, pinkish orange hymenium that is sharply demarcated from the dull orange stipe are distinctive. While the long basidia of C. kunmudlutsa also are distinctive, this species is otherwise micromorphologically typical of acystidiate Clavulina species with clamped, thin-walled tramal hyphae (Corner 1950). Sequence data from both the ITS and 28S confirm the generic placement of C. kunmudlutsa.

Clavulina kunmudlutsa is similar to C. panurensis (Berk.) Corner from Brazil and Venezuela (Corner 1950, 1970) in basidioma size, stature and basidiospore size, and both have clamped trama hyphae with similar cellular dimensions. Clavulina panurensis differs from C. kunmudlutsa in having a white to pale ochraceous, brittle-textured basidioma with stout, flattened branches with flat branch axils, shorter basidia, 36-50 $\mu \mathrm{m}$ vs. 47-69(77) $\mu \mathrm{m}$, and consistently multiguttulate basidiospores (Corner 1970). Among Congolian Clavulina species, C. kunmudlutsa shares a similar basidioma size, branching pattern, and basidiospore morphology with C. ramosior (Corner) P. Roberts, along with an association with caesalpinioid leguminous ECM host trees. Clavulina ramosior can be distinguished by its dull pink, nearly astipitate basidiomata and much shorter basidia (30-40 $\mu \mathrm{m}$; Roberts 1999, Douanla-Meli 2007). Clavulina kunmudlutsa is one of the most prized edible fungi of the Patamona Amerindians of the central Pakaraima Mountains (Henkel et al. 2004).

Clavulina tepurumenga T.W. Henkel et Aime, sp. nov.

\section{MycoBank MB518849}

FIGS. 3, 4

Clavulina tepurumenga cinereis vel murinis basidiomatis per omnes periodos temperatae Clavulinae cinereae (Fr.) Schroet. similis, sed gracilioribus, laxe ramosis basidiomatis cum angustis, non-rugulosis stipitibus, ubique magis atrocinereis differt.
Basidiomata coralloid, terrestrial, arising from soil humic layer, branched, in caespitose clusters, more rarely solitary or in pairs, somewhat fused basally, with acuminate basal primordia initially monopodial but branching early with expansion; caespitose clusters 40-166 mm tall, 16-68 mm wide across branches, 6$14 \mathrm{~mm}$ across basal stipe cluster; individual basidiomata branching 3-6(9) times in multiple planes, branching pattern dichotomous-ascending, more polychotomous distally, apices rounded-acuminate, more blunt with age, texture pliant-cartilaginous; sterile stipe $8-26 \times 2-4 \mathrm{~mm}$, gray-brown (5C4-5C5) to dark gray-brown (7F3-7F4), glabrous, round to flattening and subcanaliculate with age, often sterile up to or beyond the second branching point; fertile branches 32-140 mm long, 1.5-3.5 mm wide, flattening somewhat with age; hymenium ripening over distal one-half to two-thirds of basidioma, amphigenous, interface with stipe sharply demarcated and angular, sometimes extending below first branching point, initially light lilac-gray (9D2), maturing to deeper purplish gray (10D2-10E2-10E3), light creamish gray with drying, thickening moderately from $0.1-$ $0.4 \mathrm{~mm}$, smooth, finely hispid under hand lens, moist; trama concolorous with stipe, subsolid, somewhat hollow toward base. Spore deposit not obtained. Odor fragrant, fruity; flavor nutty, tangy with faintly bitter aftertaste. Basidiospores 7-9 × 6-7 $\mu \mathrm{m}$ (mean Q $=1.19$ ), subglobose, smooth, hyaline in $\mathrm{H}_{2} \mathrm{O}$, pale yellow in $\mathrm{KOH}$, inamyloid, with one translucent guttule, occasionally multi-guttulate, inamyloid; wall $1 \mu \mathrm{m}$ thick; hilar appendage $1 \mu \mathrm{m}$ long. Basidia 42$57 \mu \mathrm{m}$ long, 3-6 $\mu \mathrm{m}$ wide at apex, 3.5-7.4 $\mu \mathrm{m}$ at center, 3-5 $\mu \mathrm{m}$ at base, broadly cylindrical, with numerous grayish granular contents, basally clamped; postpartal septa observed in most basidia, occurring 14.8-19.8 $\mu \mathrm{m}$ below apex; sterigmata 5-7 $\mu \mathrm{m}$ long, cornute, two per basidium. Basidioles numerous. Cystidia none. Hymenium in transverse section 49$74 \mu \mathrm{m}$ thick. Tramal hyphae smooth, thin-walled, hyaline, lacking internal contents; cells barely inflating, 24-49(66) $\times$ 2.5-7.4(12) $\mu \mathrm{m}$. Clamp connections abundant.

Holotype. Henkel 8217 (BRG; ISOTYPE HSU; NY; DUKE)

Habit, habitat and distribution. Scattered, caespitose, in pairs or rarely solitary in humus layers on lateritic ironstone soils in D. corymbosa-dominated forests; common throughout May-Jul rainy season; basidiomata persistent 1-3 wk. Known from the upper basins of the Potaro and Mazaruni rivers in the Pakaraima Mountains of Guyana.

Etymology. "Tepurumeng" is the vernacular name applied to this fungus by the Patamona Amerindians, who collect it as an edible species. 

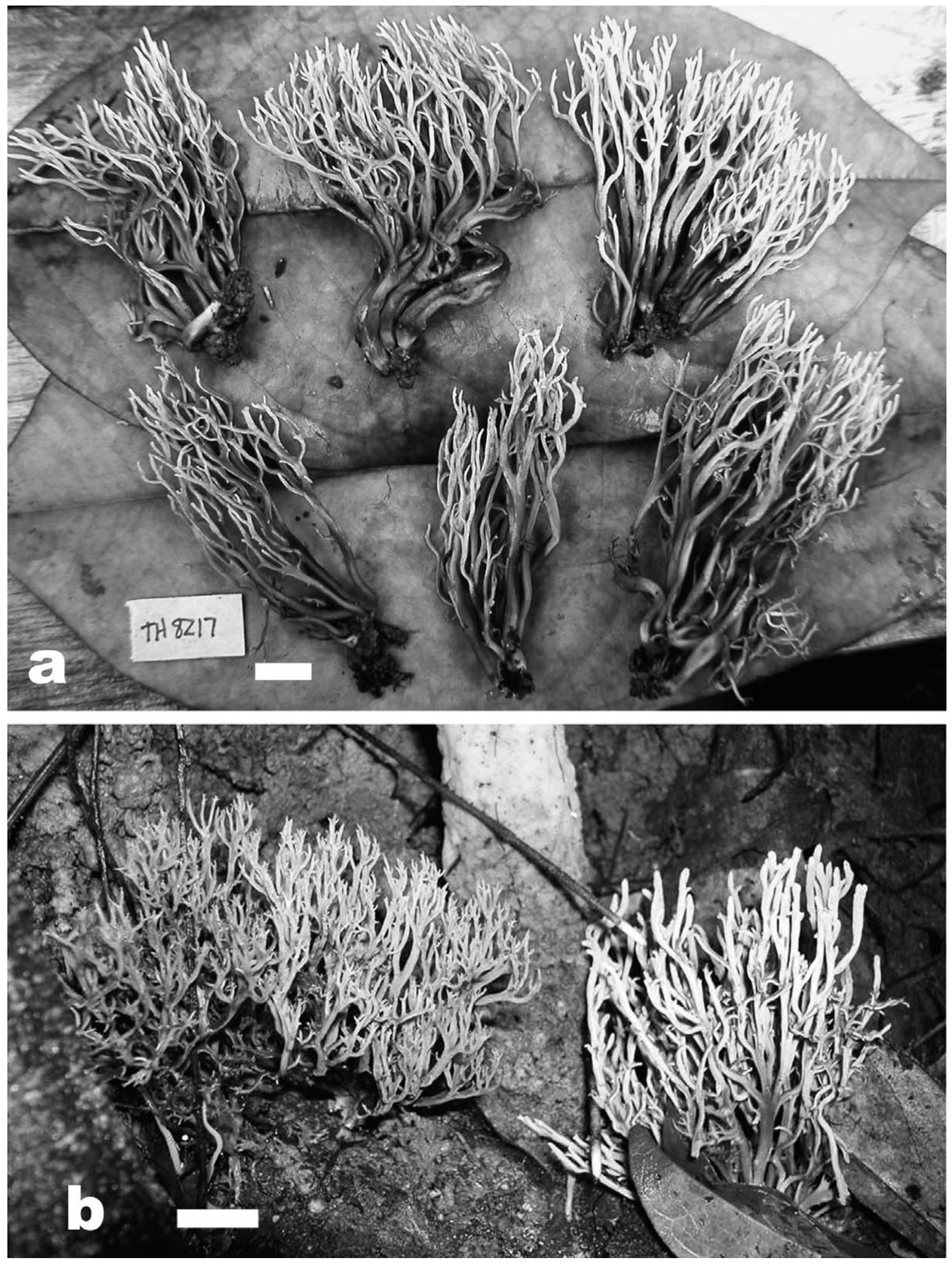

Fig. 3. Basidiomata of Clavulina tepurumenga. a. HOLOTYPE (Henkel 8217). b. Field habit, Upper Potaro Basin, Guyana. Bar $=10 \mathrm{~mm}$. 


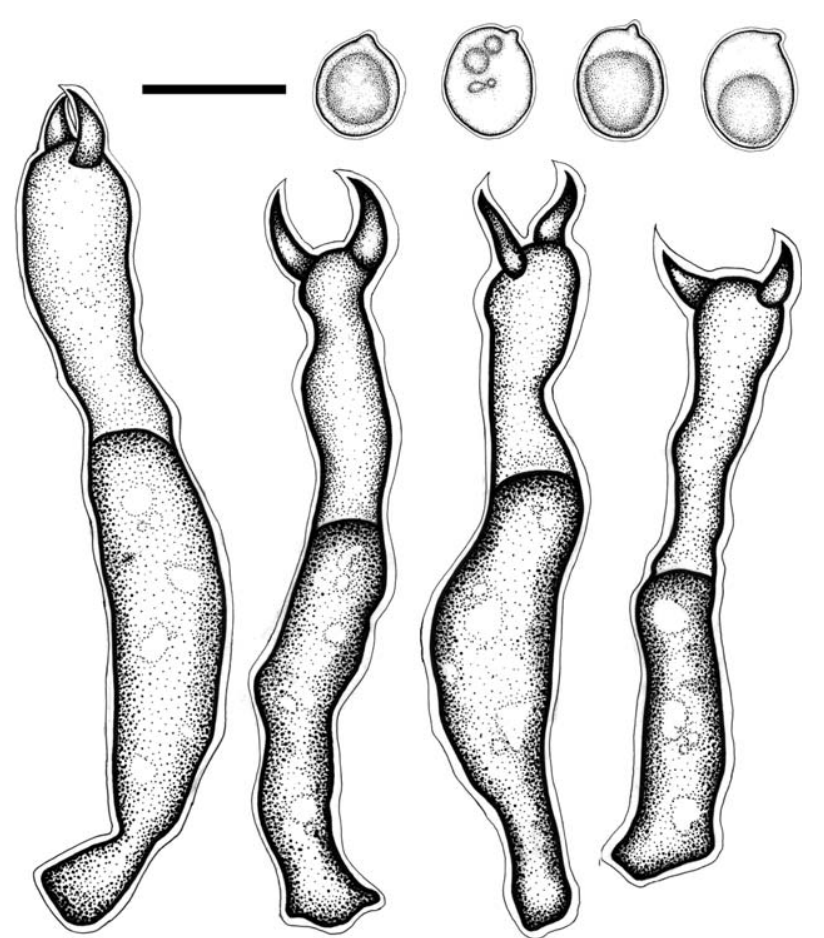

FIG. 4. Basidia and basidiospores of Clavulina tepurumenga (HOLOTYPE; Henkel 8932). Bar $=10 \mu \mathrm{m}$.

Specimens examined. GUYANA. REGION 8 POTAROSIPARUNI: Pakaraima Mountains, Upper Potaro River Basin, within $10 \mathrm{~km}$ radius of $5^{\circ} 18^{\prime} 04.8^{\prime \prime} \mathrm{N}, 59^{\circ} 54^{\prime} 40.4^{\prime \prime} \mathrm{W}$, 710-750 m; 2 km southeast of base camp near Dicymbe plot 2, 2 Jun 2000, Henkel 7431 (BRG; HSU); 3 km southwest of base camp near Dicymbe plot 3, 23 May 2001, Henkel 8217 (HOLOTYPE BRG; ISOTYPE HSU; NY; DUKE; ITS GenBank accession number HQ680357); $2.5 \mathrm{~km}$ southeast of base camp in mixed forest plot 2, 25 Jun 2002, Henkel 8498 (BRG; HSU); $1 \mathrm{~km}$ northeast of base camp near Leon's camp, 24 May 2010, Henkel 9219 (BRG; HSU); $1.5 \mathrm{~km}$ east of Ayanganna airstrip on ironstone ridge north of Potaro River, 7 Jun 2010, Henkel 9259 (BRG; HSU); vicinity of old Ayanganna airstrip, 18 May 2000, Aime 979 (BRG; LSUM); $1.5 \mathrm{~km}$ southeast of base camp in Dicymbe plot 1, 25 May 2001, Aime 1626 (BRG; LSUM); $1 \mathrm{~km}$ west of base camp, 27 Jun 2006, Aime 3116 (BRG; LSUM; 28S GenBank accession number HQ680363); $\sim 4.5 \mathrm{~h}$ walk NE of Kopinang Village, near $5^{\circ} 03^{\prime} 0.0^{\prime \prime} \mathrm{N}, 59^{\circ} 48^{\prime} 0.0^{\prime \prime} \mathrm{W}, 640 \mathrm{~m}$, on ground along creek in Dicymbe-dominated forest, $19 \mathrm{Jul}$ 1989, Samuels 6642 (TENN 59036!); Kopinang Mountain, SE slope along Kopinang-Orinduik Trail, $1.5 \mathrm{~h}$ walk $\mathrm{S}$ of Kopinang Village on steep slope, near $4^{\circ} 57^{\prime} 0.0^{\prime \prime} \mathrm{N}$, $59^{\circ} 53^{\prime} 0.0^{\prime \prime} \mathrm{W}, 750-790 \mathrm{~m}$, on ground under caesalpinioid legumes, 22 Jul 1989, Samuels 6649 (TENN 51400!). REGION 7 CUYUNI-MAZARUNI: Pakaraima Mountains, Upper Mazaruni River Basin, foothills immediately $\mathrm{S}$ of Mount Ayanganna, $\sim 1 \mathrm{~km} \mathrm{~W}$ of Pong River, on ground in forest dominated by Inga, Dicymbe and Swartzia, near $5^{\circ} 28^{\prime} 0.0^{\prime \prime} \mathrm{N}, 60^{\circ} 04^{\prime} 0.0^{\prime \prime} \mathrm{W}, 550-600 \mathrm{~m}, 26$ Feb 1987, Samuels 4804 (TENN 51385!).
Commentary. Clavulina tepurumenga is recognized in the field by its relatively large, highly branched basidioma with a gray-brown stipe that contrasts with the creamish to purplish gray hymenium. This species is usually caespitose and scattered but occasionally solitary on the forest floor under $D$. corymbosa. In the type locality of Guyana's Upper Potaro Basin $C$. tepurumenga fruits preferentially in Dicymbe forests on lateritic ironstone soils, in contrast to the apparent white sand preference of C. kunmudlutsa. For most micromorphological features the species is typical of acystidiate Clavulina species with clamped, thin-walled tramal hyphae, although the lack of significantly inflated tramal hyphae is distinctive (Corner 1950). Sequence data from both the ITS and $28 \mathrm{~S}$ confirm the generic placement of C. tepurumenga.

Among previously described clamped, acystidiate Clavulina species, none are similar to C. tepurumenga. Few species are known that combine these micromorphological features with gray to purplish gray basidiomata through all stages of development (e.g. Corner 1970, Petersen 1983). Varieties of the temperate C. cinerea (Fr.) Schroet. can be distinguished from C. tepurumenga by their relatively stout basidiomata with compact branches, gray to dark cinereous with purplish tones throughout, and a short, rugulose stipe (Corner 1950, 1970; Olariaga et al. 2009). Clavulina puiggarii (Speg.) Corner, known from the West Indies, South America, Malaysia and Australia, also lacks cystidia and has clamp connections and branched basidiomata that turn gray with maturation. However this species differs from C. tepurumenga in its much smaller basidiomata (up to $45 \mathrm{~mm}$ tall), offwhite to cream stipe, clavate basidia lacking postpartal septations, and the presence of gloeoplerous hyphae in the trama of the stipe base (Corner 1970, Petersen 1983). Clavulina mussooriensis Corner, Thind \& Dev. from the Himalayas has dark-colored basidiomata of similar stature but differs from C. tepurumenga in its gray-brown to brown branches with persistently creamish white tips, white stipe base, nonclamped basidia and cylindrical emergent hyphae scattered throughout the hymenium (Corner et al. 1958, Thind 1961, Corner 1970). Clavulina tepurumenga is a highly esteemed edible fungus that is used by the Patamona Amerindians of the central Pakaraima Mountains (Henkel et al. 2004).

\section{Clavulina amazonensis Corner Beih. Nova Hedwigia 33:151-152. 1970. FIG. 5}

Basidiomata coralloid with narrow, wiry branches, terrestrial, arising from upper layers of mineral soil, densely gregarious or in caespitose clusters with fused bases; caespitose clusters 78-129 mm tall, 13-88 mm 


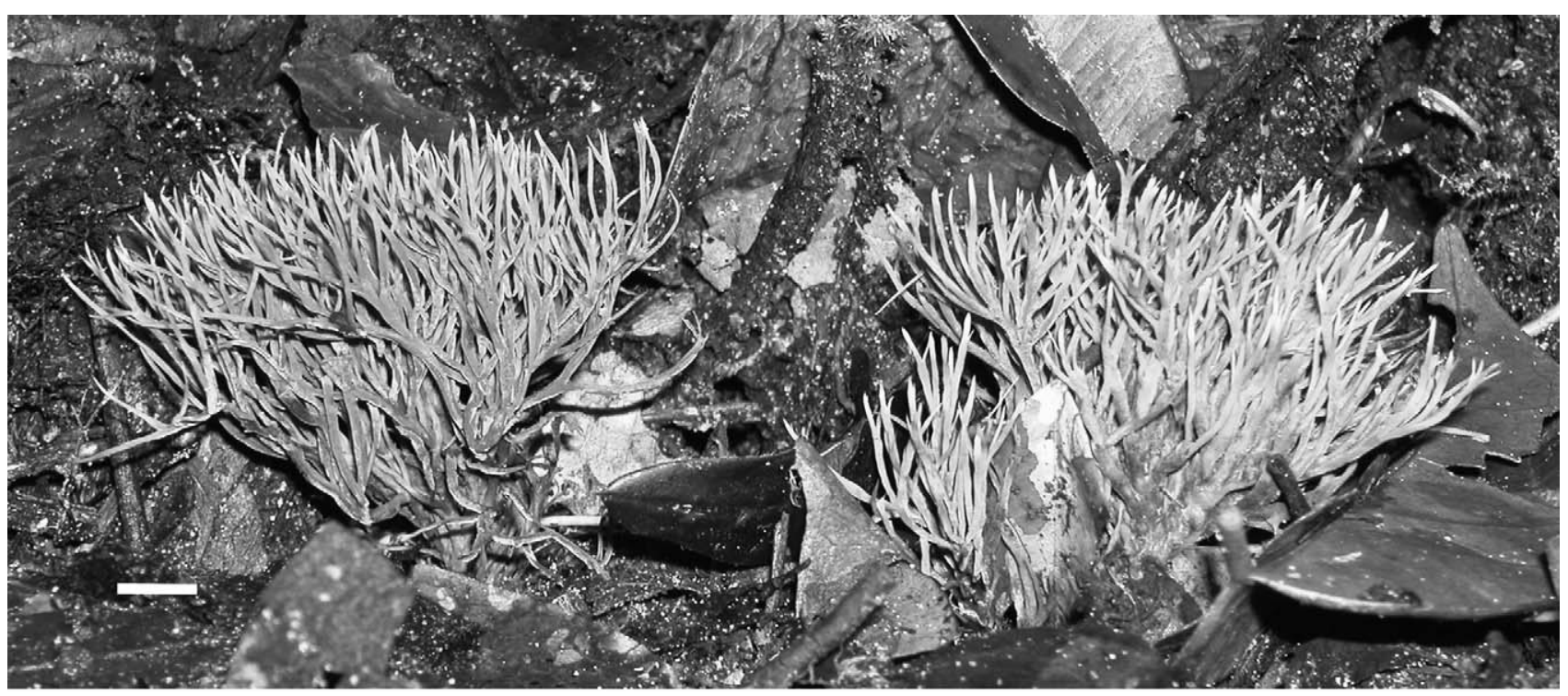

FIG. 5. Field habit of Clavulina amazonensis, Upper Potaro Basin, Guyana. Bar $=10 \mathrm{~mm}$.

across branches; individual basidiomata branching 69 times, branching pattern dichotomous-ascending below, more polychotomous distally, distal branches regularly superficially fusing, 41-129 $\mathrm{mm}$ tall, 11$18 \mathrm{~mm}$ across branches, branch apices acuminate, blunt-rounded in late development from hymenial thickening; texture wiry-cartilaginous; sterile stipe 10$41 \times 1-3 \mathrm{~mm}$, dull brownish orange $(6 \mathrm{C} 7-6 \mathrm{~B} 7,7 \mathrm{E} 7-$ $7 \mathrm{E} 8)$, tough, somewhat rugulose, extreme base concolorous and substrigose, with adhering soil; fertile branches $31-88 \times 0.5-2 \quad(5) \mathrm{mm}$, initially rich brownish orange (6A7-6B 7$)$, transitioning sharply over distal 5-10 $\mathrm{mm}$ to creamish yellow (4A8), distal tip white (5A1) and acuminate initially; hymenium developing above first branching point, initially somewhat unilateral, ultimately amphigenous, progressively thickening from $0.2-2 \mathrm{~mm}$, this resulting in superficial fusion of branches at contact points and blunt rounding of apices, hispid under handlens when young, initially light grayish orange (5A3-5A5), maturing to a sordid grayish orange (5B4-5D4), in transverse section with minute concentric rings under handlens, moist; trama dark brownish orange and solid throughout. Spore deposit pale cream. Odor fragrant, somewhat fruity; flavor nutty, slightly tangy. Basidiospores 6-7.5 $\times 5-7 \mu \mathrm{m}$ (mean $\mathrm{Q}=1.23$ ), subglobose, hyaline in $\mathrm{H}_{2} \mathrm{O}$ and $\mathrm{KOH}$, inamyloid, with single large, opaque guttule, occasionally with multiple guttules of various sizes; wall $1 \mu \mathrm{m}$ thick; hilar appendix prominent, $1 \mu \mathrm{m}$ long. Basidia 46$74 \mu \mathrm{m}$ long, 4.9-7.4(10) $\mu \mathrm{m}$ wide at apex, 3.7-6.2(7.4) $\mu \mathrm{m}$ at center, $2.5-4.9(7.5) \mu \mathrm{m}$ at base, subclavate, occasionally with hyaline guttules, hyaline in $\mathrm{H}_{2} \mathrm{O}$, faintly yellowish in $\mathrm{KOH}$, walls $0.6-0.8 \mu \mathrm{m}$ wide, postpartal septa not observed; sterigmata (2.5) 3.7-5 (6.2) $\mu \mathrm{m}$ long, cornute, occasionally with out-flaring apices, broadening substantially toward base, two or three per basidium. Basidioles numerous. Cystidia none. Hymenium in transverse section 99-198 $\mu \mathrm{m}$ thick. Tramal hyphae smooth, lacking obvious internal contents; cells $26-66 \times 2.5-5 \mu \mathrm{m}$, uninflated, flaring outward slightly at septa, orange-tan, some nearly hyaline, with walls thickening to $0.5-1 \mu \mathrm{m}$, occasionally skeletalized with walls nearly occluding the lumen. Clamp connections absent.

Habit, habitat and distribution. In Guyana, scattered and frequent during the May-Jul rainy season in the Upper Potaro and Upper Ireng river basins, arising from upper layers of mineral soil in forests dominated by Dicymbe corymbosa, also found in association with Dicymbe altsonii Sandw. and Aldina insignis (Benth.) Endl.; basidiomata persistent over several weeks; also known from the central Brazilian Amazon and southern Venezuela.

Specimens examined. GUYANA. REGION 8 POTAROSIPARUNI: Pakaraima Mountains, Upper Ireng River Basin, $850 \mathrm{~m}$, toe slopes of Mount Kukuinang, $2 \mathrm{~km}$ west of Sukabi/Ireng confluence, 23 May 1998, Henkel 6559 (BRG; HSU); west bank of Ireng River $1 \mathrm{~km}$ upstream from confluence with Yuarka Creek, 31 May 1999, Henkel 7093 (BRG; HSU); Upper Potaro River Basin, within $10 \mathrm{~km}$ radius of $5^{\circ} 18^{\prime} 04.8^{\prime \prime} \mathrm{N}, 59^{\circ} 54^{\prime} 40.4^{\prime \prime} \mathrm{W}, 710-750 \mathrm{~m} ; 3 \mathrm{~km}$ southwest of base camp near Dicymbe plot 3, 4 Jun 2001, Henkel 8239 (BRG; HSU); vicinity of base camp, 13 Jun 2002, Henkel 8463 (BRG; HSU); $3 \mathrm{~km}$ southeast of base camp in mixed forest plot 2, 25 Jun 2002, Henkel 8500 (BRG; HSU); $2.5 \mathrm{~km}$ southeast of base camp near Dicymbe plot 2, 3 Jul 2003, Henkel 8532 (BRG; HSU); vicinity of base camp, 5 Jul 2004, Henkel 8742 (BRG; HSU; 28 S GenBank 
accession number HQ680361); $1.5 \mathrm{~km}$ southeast of base camp along Benny's Ridge, near Dicymbe plot 1, 14 May 2010, Henkel 9191 (BRG; HSU; ITS GenBank accession number HQ680356); $2 \mathrm{~km}$ southeast of base camp near Dicymbe plot 2, 26 May 2010, Henkel 9223 (BRG; HSU); vicinity of old Ayanganna airstrip, 22 May 2000, Aime 1006 (BRG; LSUM); $0.5 \mathrm{~km}$ west of base camp, 18 Jun 2002, Aime 2070 (BRG; LSUM; 28S GenBank accession number HQ680360); $4.5 \mathrm{~h}$ walk NE of Kopinang Village, near $5^{\circ} 03^{\prime} 0.0^{\prime \prime} \mathrm{N}, 59^{\circ} 48^{\prime} 0.0^{\prime \prime} \mathrm{W}, 640 \mathrm{~m}$, on ground along

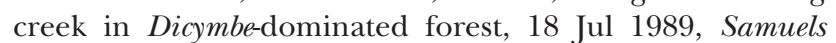
6622 (TENN 51394!). VENEZUELA. AMAZONAS: Ocamo, 12 Aug 1987, Halling 5485 (TENN 47649!).

Commentary. Clavulina amazonensis is recognized in the field by its gregarious to caespitose, highly branched, wiry-cartilaginous basidiomata arising from the upper layers of mineral soil, dull orange, often fused stipes transitioning upward into narrow, orange branches with white to cream acuminate tips. The hymenium develops and thickens patchily to amphigenously over the branches to various shades of grayish orange and results in the superficial fusing of branches at contact points. Information on fruiting frequency is lacking for sites in Brazil and Venezuela, but in our permanent study plots in Guyanese Dicymbe forests $C$. amazonensis is the second most frequent fruiter among 129 species of putative ECM fungi. This species has occurred in $71.4 \%(450 / 630)$ of $10 \times 10 \mathrm{~m}$ fruiting body subsampling plots over 9 y of rainy season sampling (Aime and Henkel 2008, unpubl data). Collections examined here constitute the first records for the species from Guyana. Sequence data from both the ITS and 28S confirm the generic placement of $C$. amazonensis.

Guyanese collections of $C$. amazonensis agree well with the distinctive morphology of collections from Brazil (type; Corner 1970) and Venezuela, amply illustrated by Petersen (1988b). Whereas previous studies were based on single collections, we have collected a large number of specimens and have seen C. amazonensis through all stages of development of its highly persistent basidiomata. Macromorphologically the Guyanese material is similar to that of Brazil and Venezuela in coloration, branching pattern and texture, although many of our basidiomata are taller (up to $129 \mathrm{~mm}$ vs. 65-90 mm). Micromorphological features are largely consistent among all known collections of the species, including such distinctive aspects as the orangish brown, uninflated, thickwalled tramal hyphae, two- or three-sterigmate, thick-walled basidia, and cornute sterigmata with broad bases and flaring tips. As with Petersen's studies of the Venezuelan material, we found no evidence in the Guyanese collections of the foursterigmate basidia reported for the type (Corner 1970, Petersen 1988b). The Guyanese collections deviate from those from Brazil and Venezuela only in their slightly narrower basidia, 4.9-7.4(-10) vs. 7.59.5 vs. $7-9 \mu \mathrm{m})$.

The report of C. amazonensis from Guyana constitutes a significant range extension for the species. The type collection is from near Manaus, Brazil, (Corner 1970) and a second collection was reported from Amazonas, Venezuela (Petersen 1988b). With the inclusion of Guyana the known distribution of this species spans a triangular area nearly $800 \mathrm{~km}$ on each side and covers a large portion of the central Guiana Shield region. Although confirmations of ECM host plants were not made in conjunction with the Brazilian and Venezuelan collections, the broad regional distribution of C. amazonensis is suggestive of a general distribution of ECM fungi and host plants over a similar area. Such distributional data for individual, putative ECM Clavulina species, coupled with molecular confirmation of Clavulina spp. as ECM mycobionts on roots of Dicymbe and Aldina in Guyana (Smith and Henkel 2010), the dipterocarp Pakaraimaea dipterocarpaceae in Venezuela (Moyersoen 2006) and Coccoloba spp. (Polygonaceae) in eastern Ecuador and Guyana (Tedersoo et al. 2010, Smith and Henkel unpubl data), suggest a widespread association of Clavulina species with diverse host plants over a broad area of the South American tropics.

Clavulina sprucei (Berk.) Corner, A monograph of Clavaria and allied genera. 341. 1950. FIGS. 6, 7

三 Clavaria sprucei Berk., Hook. J. Bot. 8:276. 1856, nom. nov.

Basidiomata coralloid, branching dichotomously upward 2-6 times, more polychotomously distally, 948 mm tall, 10-39 (50) mm across branches, branches persistently isodiametric, apices sharply acuminate throughout development, initially off-white to pale creamish white (2A1-2A2) throughout, with age cream (3A2-3A3); sterile stipe 7-12 × 0.5-1.75 mm, concolorous, hispid under hand lens, with dull white byssoid to tomentulose basal pad on flat litter substrata; hymenium ill-defined, amphigenous over central branches and possibly portions of the stipe, concolorous, thickening to $\sim 0.2 \mathrm{~mm}$ but not distorting branches, hispid under handlens, moist; trama concolorous, subsolid. Basidiomata frequently infested superficially with developing, tiny black ascomata of an unidentified sordarialean parasite. Spore deposit not obtained. Odor and flavor none. Basidiospores 8-10 × 6.5-8 $\mu \mathrm{m}$ (mean $\mathrm{Q}=1.34$ ), subellipsoid, tapering evenly and slightly toward base in adaxial view, hyaline in $\mathrm{H}_{2} \mathrm{O}$ and $\mathrm{KOH}$, inamyloid, with single large, opaque guttule, occasionally with numerous variously sized guttules; hilar appendix prominent, 0.75-1.25 $\mu \mathrm{m}$ long. Basidia 29-44 (49) $\mu \mathrm{m}$ 


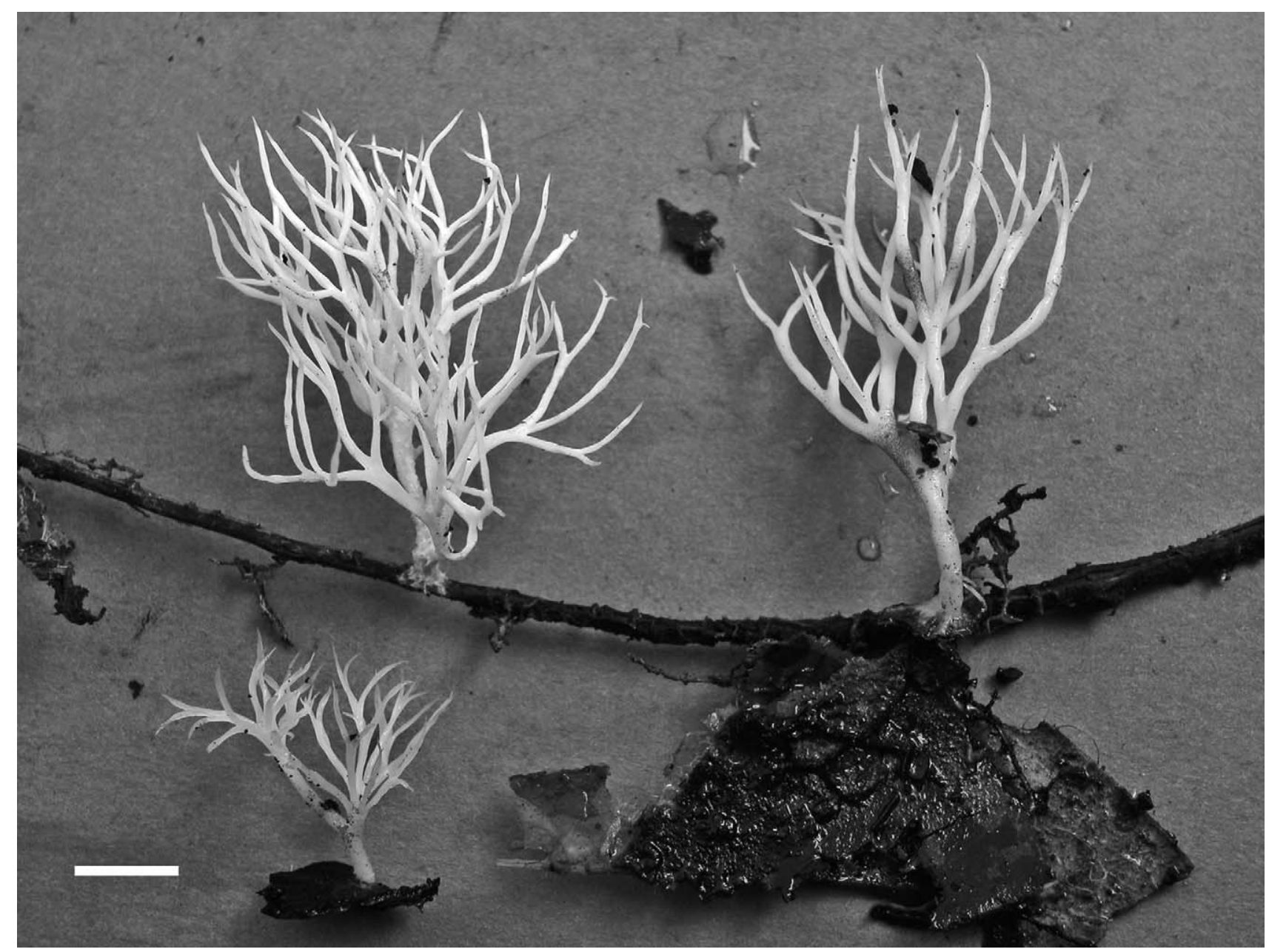

FIG. 6. Basidiomata of Clavulina sprucei (Henkel 9210). Bar $=10 \mathrm{~mm}$.

long, subcylindrical to cylindrical, width at apex 2.5$7.5 \mu \mathrm{m}$, at center 2.4-7.4 $\mu \mathrm{m}$, at base 2.5-4.9 (7.4) $\mu \mathrm{m}$, hyaline in $\mathrm{H}_{2} \mathrm{O}$ and $\mathrm{KOH}$, gloeoplerotic; postpartal septa frequent, occurring 7.4-14.9 $\mu \mathrm{m}$ below apex, initially planar, later outcurving distally and causing a slight lateral constriction in basidium; postpartal basidium apex often evacuated and collapsed, with basal portion remaining turgid. Basidioles numerous. Cystidia none. Tramal hyphae smooth, thin-walled, hyaline, moderately inflated, lacking internal contents; cells 49-72 $\mu \mathrm{m}$ long; uninflated elements 2.5$9.9 \mu \mathrm{m}$ wide; inflated elements up to $19.8 \mu \mathrm{m}$ wide. Clamp connections absent.

Habit, habitat and distribution. Scattered, gregarious, or in troops on partially decayed leaves and small woody substrata on the forest floor or root mounds and pseudo trunks of $D$. corymbosa; frequent during May-Jul rainy season, also fruiting in Dec-Jan. Known from the Upper Potaro Basin of Guyana and the type locality in the Vaupes Basin of northwestern Brazil.

Specimens examined. GUYANA. REGION 8 POTAROSIPARUNI: Pakaraima Mountains, Upper Potaro River
Basin, within $15 \mathrm{~km}$ radius of $5^{\circ} 18^{\prime} 04.8^{\prime \prime} \mathrm{N}, 59^{\circ} 54^{\prime} 40.4^{\prime \prime} \mathrm{W}$, 710-750 m; vicinity of base camp, 22 Jun 2000, Henkel 7537 BRG; HSU); 2 km southeast of base camp, 29 May 2001, Henkel 8221 (BRG; HSU; ITS GenBank accession number HQ680354); $15 \mathrm{~km}$ east of base camp, vicinity of Tadang Creek, 21 Dec 2009, Henkel 9122 (BRG; HSU; ITS GenBank accession number HQ680355); $1.5 \mathrm{~km}$ west of base camp near Dicymbe masting plot 1, 23 May 2010, Henkel 9210 (BRG; HSU; ITS and partial 28S GenBank accession number HQ680353); $1.5 \mathrm{~km}$ east of Ayanganna airstrip on ironstone ridge north of Potaro River, 7 Jun 2010, Henkel 9265 (BRG; HSU); vicinity of base camp, in Dicymbe forest, 28 May 2000, Aime 1073 (BRG; LSUM); vicinity of base camp, 4 Jul 2006, Aime 3182 (BRG; LSUM); $2 \mathrm{~km}$ southeast of base camp near Dicymbe plot 1, 15 May 2010, Aime 3924 (BRG; LSUM; HSU); 2 km west of base camp in Dicymbe plot 3, 20 May 2010, Aime 3989 (BRG; LSUM; HSU; ITS GenBank accession number HQ680352). BRAZIL. AMAZONAS. Rio Vaupes watershed, Panure; on decayed trunks and branches, 1853, Spruce 26, Clavulina sprucei (Berk.) Corner (HOLOTYPE, K(M) 167808a!); on dead leaves and twigs, Mar 1853, Spruce 161, Clavulina delicia (Berk.) Corner (HOLOTYPE K(M) 167809a!; ISOTYPE FH ex folder 131!); on shady ground in woods, 1853, Spruce 10, 


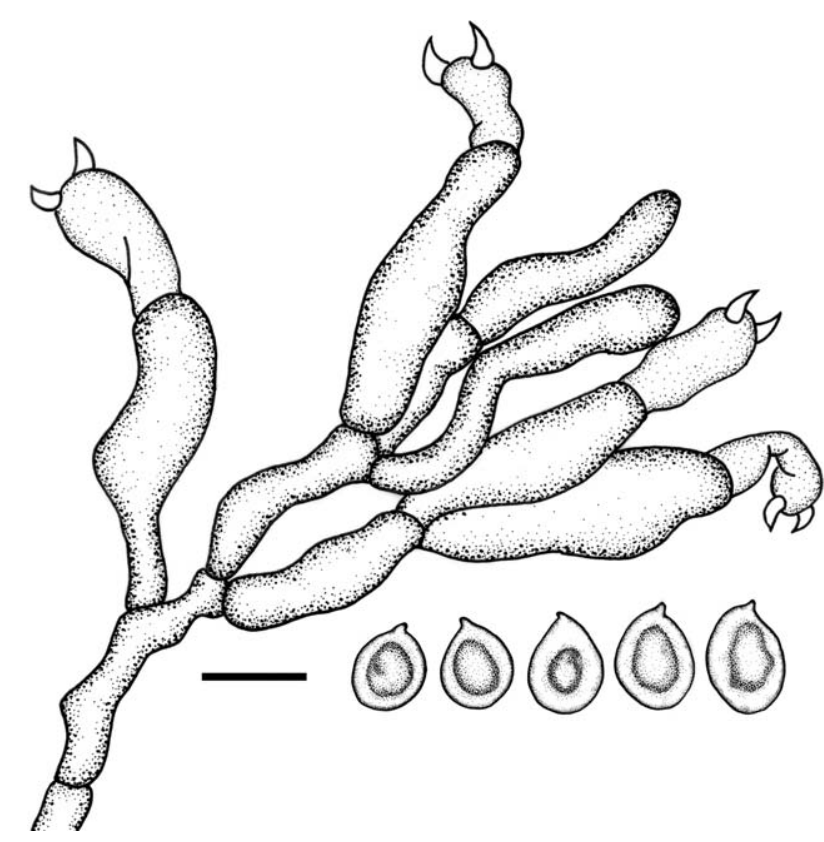

Fig. 7. Basidia and basidiospores of Clavulina sprucei (Henkel 9210). Bar $=10 \mu \mathrm{m}$.

Clavulina connata (Berk.) Corner (HOLOTYPE K(M) 167811!).

Commentary. Clavulina sprucei is recognized in the field by its small, gracile, off-white to cream basidiomata occurring scattered to more often in troops on a variety of partially decomposed litter components in the immediate vicinity of Dicymbe and Aldina trees. Clavulina sprucei can be found on litter accumulations permeated by ectomycorrhizas 1-3 $\mathrm{m}$ above ground on the complex pseudo trunks of $D$. corymbosa, a habit also noted for other Clavulina spp. from Guyana (Henkel et al. 2005, Woolley et al. 2008). Close inspection of the diminutive basidiomata reveals a concolorous hispid stipe with a distinct byssoid to tomentulose basal pad when fruiting on flat substrata. Also the frequent occurrence of minute, black fruiting bodies of a sordarialean ascomycete parasite on the lower basidioma is distinctive. Morphologically $C$. spruce $i$ is distinguished by its subellipsoid, uniguttulate basidiospores that taper evenly and slightly toward the base in adaxial view and postpartal basidia with a slight lateral constriction at the secondary septum, with the apical portion often evacuated and collapsed. All morphological aspects of the Guyanese collections are consistent with those reported for the Brazilian Clavulina sprucei (Berk.) Corner (Berkeley 1856; Corner 1950, 1970) and confirmed by our examination of its type at Kew. Sequence data from both the ITS and 28S support the generic placement of $C$. sprucei. The ECM status of C. sprucei has been confirmed by recovery of $C$. sprucei ITS rDNA

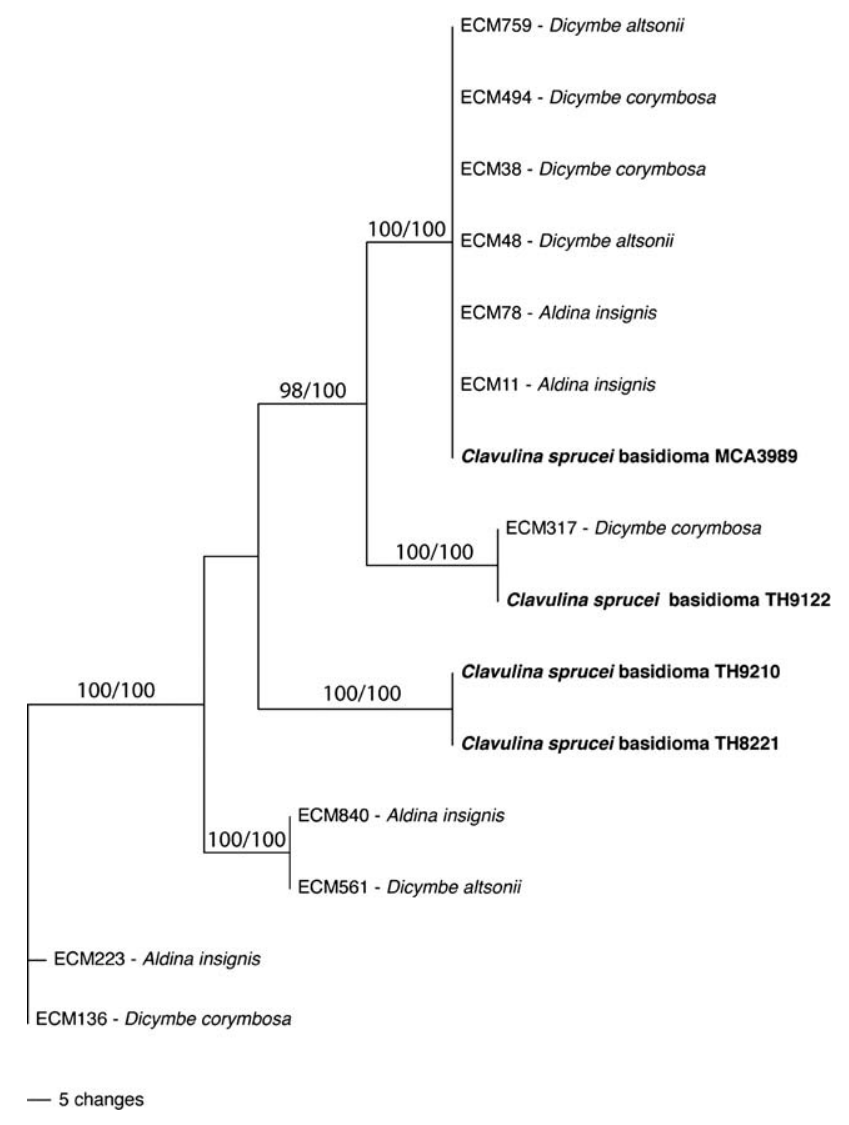

FIG. 8. Most parsimonious phylogram of the Clavulina sprucei species complex in Guyana based on ITS rDNA sequences from morphologically identical basidiomata and ectomycorrhizal (ECM) roots of Dicymbe corymbosa, Dicymbe altsonii, and Aldina insignis. The tree was midpoint rooted and MP and ML bootstrap support values are shown. GenBank accession numbers for the ITS of the 11 ECM roots are HQ680341-HQ680351.

sequences from ECM roots of D. corymbosa, D. altsonii and A. insignis (FIG. 8).

Phylogenetic analyses of ITS sequences obtained from basidiomata and ectomycorrhizas suggest that in Guyana C. sprucei might be a complex of several species-level taxa. We detected three distinct ITS types among sympatric basidioma collections. Two additional ITS types of the C. sprucei group are known only from ECM root sequences recovered in an ongoing below-ground molecular survey (Smith and Henkel unpubl data). These ITS sequences are ca. 87-93\% similar other across the ITS1-5.8s-ITS2 region and under phylogenetic analysis fall into five well supported clades (FIG. 8). However assessment of macro- and micromorphology of collections assigned to each of the three ITS groups containing sequenced basidiomata have revealed no significant or consistent morphological variations between them or from the type of C. sprucei. Although the well supported ITS 
groups suggest that C. sprucei is composed of several morphologically cryptic species, more studies are needed to fully differentiate the taxa within this group.

Clavulina delicia (Berk.) Corner, also collected by Richard Spruce from the Rio Vaupes in Brazil, is similar to C. sprucei in basidioma size, coloration and fruiting habit but differs in its basidiospores that are longer $(9.5-11 \mu \mathrm{m}$ vs. $8-10 \mu \mathrm{m})$ with a higher mean $Q$ (1.85 vs. 1.34) and its unilateral hymenium development, confirmed by our examination of the type of $C$. delicia. Clavulina connata (Berk.) Corner, also from the Vaupes, resembles C. sprucei in its relatively small, finely branched basidiomata with similar coloration but differs in its consistently taller basidiomata (40$50 \mathrm{~mm}$ vs. 9-48 mm), narrower basidiospores (5.5$6.5 \mu \mathrm{m}$ vs. $6.5-8 \mu \mathrm{m})$, longer basidia $(40-65 \mu \mathrm{m}$ vs. 29 $44 \mu \mathrm{m})$ and habit of fruiting directly from the soil (Berkeley 1856; Corner 1950, 1970).

In permanent study plots in Guyanese Dicymbe forests $C$. sprucei was the most frequently fruiting macromycete among 129 species of putative ECM fungi, having occurred in $78.4 \%(494 / 630)$ of $10 \times$ $10 \mathrm{~m}$ sporocarp subsampling plots over $9 \mathrm{y}$ of rainy season sampling (Aime and Henkel 2008 unpubl data). These data, in conjunction with the regular recovery of $C$. sprucei ITS rDNA sequences from ectomycorrhizas, suggest an important ecological role for this species group in Guyanese Dicymbe forests.

\section{ACKNOWLEDGMENTS}

The authors thank the following for financial support: National Science Foundation DEB-0918591 and the National Geographic Society's Committee for Research and Exploration (TWH), Harvard University Herbaria (MES), a field research gift from W.K. Smith and NSF DEB-0732968 (MCA). Field assistance in Guyana was provided by M. Chin, C. Andrew, V. Joseph, P. Joseph, F. Edmond and L. Edmond. Research permits were granted by the Guyana Environmental Protection Agency. The authors thank C. Feuillet for the Latin diagnoses and R. Petersen for access to undetermined Neotropical clavarioid collections at the University of Tennessee Fungus Herbarium. Gary Samuels is thanked for providing additional data on collections originally made by him in Guyana. Bryn Dentinger provided access to Clavulina type specimens at Kew Gardens. This paper is number 170 in the Smithsonian Institution's Biological Diversity of the Guiana Shield Program publication series.

\section{LITERATURE CITED}

Aime MC, Henkel TW. 2008. Where are the missing fungi? Western Guyana as a potential hotspot for fungal diversity. Paramaribo, Surinam: Association for Tropical Biology annual meeting (abstract).
Berkeley MJ. 1856. Decades of fungi. Hooker's J Bot 8:272280.

Corner EJH. 1950. A monograph of Clavaria and allied genera. London: Oxford Univ. Press.

. 1970. A monograph of Clavaria and allied genera. Supplement. Beih Nova Hedwig 33:1-299.

- Thind KS, Dev S. 1958. The Clavariaceae of the Mussoorie Hills (India) IX. Trans Br Mycol Soc 41:203206, doi:10.1016/S0007-1536(58) 80032-7

Douanla-Meli C. 2007. Fungi of Cameroon. Bibl Mycol 202: $1-410$.

Duhem B, Buyck B. 2007. Edible mushrooms from Madagascar 2. Clavulina albiramea comb. nov. (Cantharellales), an edible clavarioid fungus shared between African miombo and Malagasy Uapaca woodland. Nova Hedwigia 85:317-330, doi:10.1127/ 0029-5035/2007/0085-0317

Edgar RC. 2004. MUSCLE: a multiple sequence alignment method with reduced time and space complexity. BMC Bioinformatics 5:113, doi:10.1186/1471-2105-5-113

Gardes M, Bruns TD. 1993. ITS primers with enhanced specificity for basidiomycetes-application to the identification of mycorrhizae and rusts. Mol Ecol 2:113-118, doi:10.1111/j.1365-294X.1993.tb00005.x

Glenn TC, Schable NA. 2005. Isolating microsatelline DNA loci. In: Zimmer EA, Roalson EH, eds. Molecular evolution: producing the biochemical data B. San Diego, California: Academic Press. p 202-222.

Henkel TW. 2003. Monodominance in the ectomycorrhizal Dicymbe corymbosa (Caesalpiniaceae) in Guyana. J Trop Ecol 19:417-437, doi:10.1017/S0266467403003468

— , Terborgh JT, Vilgalys R. 2002. Ectomycorrhizal fungi and their leguminous hosts in the Pakaraima Mountains of Guyana. Mycol Res 106:515-531, doi:10.1017/S0953756202005919

—_, Aime MC, Chin M, Andrew C. 2004. Edible mushrooms from Guyana. Mycologist 18:104-111, doi:10.1017/S0269915X04003027

— Meszaros R, Aime MC, Kennedy A. 2005. New Clavulina species from the Pakaraima Mountains of Guyana. Mycol Prog 4:343-350, doi:10.1007/ s11557-006-0140-6

Holmgren PK, Holmgren NH, Barnett LC. 1990. Index herbariorum I. The herbaria of the world. New York: New York Botanical Garden.

Kornerup A, Wanscher JH. 1978. Methuen handbook of color. London: Eyre Methuen.

Maddison WP, Maddison DR. 2006. Mesquite: a modular system for evolutionary analysis. Version 1.11. http:// mesquiteproject.org

Moyersoen B. 2006. Pakaraimea dipterocarpacea is ectomycorrhizal, indicating an ancient Gondwanaland origin for the ectomycorrhizal habit in Dipterocarpaceae. New Phytol 170:873-883, doi:10.1111/j.1469-8137. 2006.01718.x

Olariaga I, Jugo BM, Garcia-Etxebarria, Salcedo I. 2009. Species delimitation in European species of Clavulina (Cantharellales, Basidiomycota) inferred from phylogenetic analyses of the ITS region and morphological 
data. Mycol Res 113:1261-1270, doi:10.1016/ j.mycres.2009.08.008

Petersen RH. 1967. Notes on Clavarioid Fungi VI. Two new species and notes on the origin of Clavulina. Mycologia 59:39-46, doi:10.2307/3756940

1983. Notes on clavarioid fungi XVIII. A preliminary outline of Clavulina in southeastern Australia. Nova Hedwigia 37:19-35.

- 1985. Notes on clavarioid fungi XX. New taxa and distributional records in Clavulina and Ramaria. Mycologia 77:903-919, doi:10.2307/3793302

. 1988a. The clavarioid fungi of New Zealand. Wellington, New Zealand: DSIR Science Information Publishing.

- 1988b. Notes on clavarioid fungi XXII. Three interesting South American collections. Mycologia 80: 571-576, doi:10.2307/3807861

Roberts P. 1999. Clavarioid fungi from Korup National Park, Cameroon. Kew Bull 54:517-539, doi:10.2307/4110853

Smith ME, Henkel TW. 2010. Ectomycorrhizal fungal diversity and community structure on three co-occurring leguminous canopy tree species in the Neotropics IX. Edinburgh: International Mycology Congress (abstract).

Swofford DL. 2002. PAUP*: phylogenetic analysis using parsimony (*and other methods). Version 4. Sunderland, Massachusetts: Sinauer Associates.

Tedersoo L, Jairus T, Horton BM, Abarenkov K, Suvi T, Saar I, Kõljalg U. 2008. Strong host preference of ectomy- corrhizal fungi in a Tasmanian wet sclerophyll forest as revealed by DNA barcoding and taxon-specific primers. New Phytol 180:479-490, doi:10.1111/j. 1469-8137.2008.02561.x

, Sadam A, Zambrano M, Valencia R, Bahram M. 2010. Low diversity and high host preference of ectomycorrhizal fungi in western Amazonia, a Neotropical biodiversity hotspot. ISME J 4:465-471, doi:10.1038/ismej.2009.131

Thacker JR, Henkel TW. 2004. New species of Clavulina from Guyana. Mycologia 96:650-657, doi:10.2307/ 3762182

Thind KS. 1961. The Clavariaceae of India. New Delhi: Indian Council of Agricultural Research.

-, Sharda RM. 1984. Three new species of clavarioid fungi from Himalayas. Indian Phytopathol 37:234-240.

Vilgalys R, Hester M. 1990. Rapid genetic identification and mapping of enzymatically amplified ribosomal DNA from several Cryptococcus species. J Bacteriol 172:42384246.

Woolley LP, Henkel TW, Sillett SC. 2008. Reiteration in the tropical monodominant tree Dicymbe corymbosa (Caesalpiniaceae) and its potential adaptive significance. Biotropica 40:32-43.

Zwickl DJ. 2006. Genetic algorithm approaches for the phylogenetic analysis of large biological sequence datasets under the maximum likelihood criterion [doctoral dissertation]. Austin: Univ Texas Press. $115 \mathrm{p}$. 